\title{
Green Michael Addition of Thiols to Electron Deficient Alkenes using KF/Alumina and Recyclable Solvent or Solvent-free Conditions
}

\author{
Eder J. Lenardão, * Danusia O. Trecha, Patrícia da C. Ferreira, Raquel G. Jacob and Gelson Perin \\ Instituto de Química e Geociências (LASOL), Universidade Federal de Pelotas, CP 354, 96010-900 Pelotas- RS, Brazil
}

\begin{abstract}
Um método simples e eficiente foi desenvolvido para a adição conjugada de tióis ao citral na presença de $\mathrm{KF} / \mathrm{Al}_{2} \mathrm{O}_{3}$ em meio livre de solvente ou usando glicerina como solvente reciclável a temperatura ambiente. O método em meio livre de solvente foi aplicado com sucesso na reação direta do tiofenol com o óleo essencial de capim limão (Cymbopogon citratus), para fornecer diretamente 3,7-dimetil-3-(feniltio)oct-6-enal, um potencial agente bactericida. O método foi estendido a outros alcenos deficientes de elétrons com excelentes resultados. Para o método em meio livre de solvente, o uso de irradiação com microondas facilitou o procedimento e acelerou a reação. O sistema catalítico e a glicerina podem ser reutilizados até três vezes sem tratamento prévio, com atividade comparável.
\end{abstract}

A general, clean and easy method for the conjugated addition of thiols to citral promoted by $\mathrm{KF} /$ $\mathrm{Al}_{2} \mathrm{O}_{3}$ under solvent-free or using glycerin as recyclable solvent at room temperature is described. It was found that the solvent-free protocol is applicable to the direct reaction of thiophenol with the essential oil of lemon grass (Cymbopogon citratus) to afford directly 3,7-dimethyl-3-(phenylthio) oct-6-enal, a potential bactericide agent. The method was extended to other electron-poor alkenes with excellent results. For the solvent-free protocol, the use of microwave irradiation facilitated the procedure and accelerates the reaction. The catalytic system and glycerin can be reused up to three times without previous treatment with comparable activity.

Keywords: solvent-free, 1,4-addition of thiols, glycerin, citral and citronellal, green chemistry

\section{Introduction}

Besides being an important commodity in the flavor and fragrance industry, the natural occurring $\alpha, \beta$-unsaturated aldehyde citral, together with its analog citronellal, are key compounds in organic synthesis. ${ }^{1}$ The conjugated addition of thiols to $\alpha, \beta$-unsaturated compounds (electron-poor alkenes) is a very useful method for new carbon-sulfur bond-forming in organic synthesis. ${ }^{2}$ This reaction also plays also critical roles in the biosynthesis and synthesis of bioactive compounds. ${ }^{3,4}$ Besides, the 1,4-addition is a highly atom-efficient, green reaction, in agreement with the second principle of green chemistry, which says that the synthetic methods should be designed to maximize the incorporation of all materials used in the process into the final product. ${ }^{5-7}$ In view of these aspects, there are a large number of reported methods for both basic and acidic promoted selective 1,4-additions, including

*e-mail: lenardao@ufpel.edu.br heterogeneous ${ }^{8-16}$ and homogeneous catalysis, ${ }^{17-19}$ as well as asymmetric versions. ${ }^{20,21}$ Thus, solid catalysts, such as basic anion-exchange resins, ${ }^{8}$ natural ${ }^{9}$ and synthetic phosphates, ${ }^{10}$ montmorillonite clays, ${ }^{11}$ solid potassium carbonate, ${ }^{12}$ base ${ }^{13}$ and acid supported on alumina ${ }^{14}$ have been used to perform the 1,4-addition of thiols to a series of electron-poor alkenes. Besides, the use of non-volatile and non-toxic solvents, such as water, ${ }^{22,23}$ ionic liquids, ${ }^{18,19}$ and ethylene glycol ${ }^{24}$ to perform the Michael addition was also described. However, the use of solid-supported catalysts in Michael addition to $\alpha, \beta$-unsaturated aldehydes has been scarcely explored ${ }^{8-16}$ and, to the best of our knowledge, the use of glycerin as a renewable and recyclable solvent for the Michael addition of thiols to electron-poor alkenes has not been described.

In the last few years, our group has studied the use of renewable feed stocks in organic synthesis, following the green and sustainable chemistry principles. ${ }^{1,15,25-28}$ As a continuation of our studies, we report herein the full results on the solvent-free Michael addition of thiols 2 to 
electron-poor alkenes $\mathbf{1}$ using $\mathrm{KF} / \mathrm{Al}_{2} \mathrm{O}_{3}$ as catalyst, as well as the use of glycerin as recyclable solvent for this reaction (Scheme 1, Table 1).

\section{Experimental}

\section{General remarks}

The ${ }^{1} \mathrm{H}$ and ${ }^{13} \mathrm{C}$ NMR spectra of $\mathrm{CDCl}_{3}$ solutions were recorded with a $200 \mathrm{MHz}$ or a $400 \mathrm{MHz}$ spectrometer (Bruker DPX), as noted. Chemical shifts are expressed as parts per million ( $\mathrm{ppm}$ ) downfield from tetramethylsilane as an internal standard. Low Resolution Mass Spectra (LRMS, EI) were obtained at $70 \mathrm{eV}$ with a Hewlett Packard EM/CG HP-5988A spectrometer. High-Resolution Mass Spectra: HR-ESI-MS were performed in the positive mode (UltrOTOF-Q system, version 1.10, Bruker Daltonics, MA, USA). The microwave irradiated reactions were performed using a Panasonic model Piccolo NN-S42BK, operating at 2.45 MHz. Merck's silica gel (230-400 mesh) was used for flash chromatography.

\section{Preparation of alumina supported potassium fluoride ${ }^{30}$}

To a $100 \mathrm{~mL}$ beaker was added alumina $\left(4.0 \mathrm{~g}\right.$ of $\mathrm{Al}_{2} \mathrm{O}_{3}$ 90, 0.063-0.200 mm, Merck), KF. $2 \mathrm{H}_{2} \mathrm{O}(6.0 \mathrm{~g})$ and water $(10 \mathrm{~mL})$. The suspension was stirred for $1 \mathrm{~h}$ at $65^{\circ} \mathrm{C}$, dried at $80{ }^{\circ} \mathrm{C}$ for $1 \mathrm{~h}$ and for an additional $4 \mathrm{~h}$ at $300{ }^{\circ} \mathrm{C}$ in an oven and then cooled in a desiccator. The content of KF is about $50 \%(\mathrm{~m} / \mathrm{m})$.

General procedure for the 1,4-addition of thiols 2 to electron-poor alkenes 1

\section{Method A}

To a pre-stirred mixture of thiol $2(1.2 \mathrm{mmol})$ and $\mathrm{KF} /$ $\mathrm{Al}_{2} \mathrm{O}_{3}(0.07 \mathrm{~g}$, obtained as described above $)$, the alkene $1(1 \mathrm{mmol})$ was added. The mixture was stirred at room temperature and the reaction progress was followed by TLC. After consuming the starting materials (see Table 1), the crude product was filtered off the solid supported catalyst by washing with ethyl acetate $(10 \mathrm{~mL})$. The solvent was evaporated under reduced pressure and the residue was purified by column chromatography over silica gel $\left(\mathrm{SiO}_{2}\right)$ eluting with hexane/ethyl acetate (98:2), yielding the products, according Table 1 .

\section{Method B}

Aforementioned mixture was stirred for $1 \mathrm{~min}$ and then irradiated in a microwave oven (a domestic Panasonic model Piccolo NN-S42BK, operating at $2.45 \mathrm{MHz}$ ) at
$548 \mathrm{~W}^{31}$ The reaction progress was followed by TLC and after completion (see Table 1), the product was extracted and purified according to that described in Method A. The catalytic system was re-used for 3 cycles, just by washing it with ethyl acetate $(3 \times 3 \mathrm{~mL})$ and drying under vacuum. The recycled catalytic system was successfully employed in both methods.

\section{Method C}

To a mixture of thiol $2(1.2 \mathrm{mmol})$ and $\mathrm{KF} / \mathrm{Al}_{2} \mathrm{O}_{3}$ $(0.07 \mathrm{~g})$ in glycerin $(1 \mathrm{~mL})$ under stirring, was added the alkene $1(1 \mathrm{mmol})$ at room temperature. The mixture was stirred at room temperature and the reaction progress was followed by TLC. After consuming the starting materials (see Table 1), the product was extracted from the glycerin by washing the mixture with dry ether $(3 \times 5 \mathrm{~mL})$. The solvent was evaporated under reduced pressure and the residue was purified according to that described in Method A. The remaining mixture of glycerin and $\mathrm{KF} / \mathrm{Al}_{2} \mathrm{O}_{3}$ was re-used up to 3 times by the simple addition of more thiol and alkene to the residue in the reaction vessel, affording the products with comparable yields. Spectral data of the Michael adducts prepared are listed below.

\section{3,7-Dimethyl-3-(phenylthio)oct-6-enal (3a $)^{8}$}

${ }^{1} \mathrm{H} \mathrm{NMR}\left(200 \mathrm{MHz}, \mathrm{CDCl}_{3}\right) \delta(\mathrm{ppm}) 1.37$ (s, 3H); 1.56$1.64(\mathrm{~m}, 2 \mathrm{H}) ; 1.64(\mathrm{~s}, 3 \mathrm{H}) ; 1.69(\mathrm{~s}, 3 \mathrm{H}) ; 2.05-2.28(\mathrm{~m}, 2 \mathrm{H})$; $2.46(\mathrm{~d}, J$ 2.6, 2H); 5.03-5.10 (m, 1H); 7.34-7.43 (m, 3H); 7.47-753 (m, 2H); $9.95(\mathrm{t}, J 2.6 \mathrm{~Hz}, 1 \mathrm{H}) ;{ }^{13} \mathrm{C}$ NMR $(50$ $\left.\mathrm{MHz}, \mathrm{CDCl}_{3}\right) \delta$ (ppm) 17.5, 22.8, 25.5, 26.0, 40.2, 49.5, 52.1, 123.2, 128.6, 129.0, 130.5, 131.9, 137.4, 201.5. MS $\mathrm{m} / \mathrm{z}$ (rel. int., \%) $243\left(\mathrm{M}^{+}-\mathrm{H}_{2} \mathrm{O}, 1.9\right), 134$ (73.8), 81 (90.8), 69 (100.0). HRMS (ESI): $m / z$ calc. for $\mathrm{C}_{16} \mathrm{H}_{22} \mathrm{OSN}[\mathrm{M}+$ $\mathrm{H}]^{+}:$263.1469; found: 263.1458 .

\section{3,7-Dimethyl-3-(propylthio)oct-6-enal (3b)}

${ }^{1} \mathrm{H}$ NMR $\left(200 \mathrm{MHz}, \mathrm{CDCl}_{3}\right) \delta(\mathrm{ppm}) 1.00(\mathrm{t}, J 7.2,3 \mathrm{H})$; 1.41 (s, 3H); 1.48-1.70 (m, 4H); 1.62 (s, 3H); 1.68 (s, 3H); 2.04-2.18 (m, 2H); 2.43-2.55 (m, 4H); 5.05-5.12 (m, 1H); $9.90(\mathrm{dd}, J 3.0$ and $2.0,1 \mathrm{H}) ;{ }^{13} \mathrm{C} \mathrm{NMR}\left(50 \mathrm{MHz}, \mathrm{CDCl}_{3}\right)$ $\delta$ (ppm) 13.8, 17.6, 22.7, 22.8, 25.6, 26.3, 29.5, 40.9, 45.7, 52.6, 123.5, 132.2, 201.6. HRMS (ESI): $\mathrm{m} / \mathrm{z}$ calc. for $\mathrm{C}_{13} \mathrm{H}_{24} \mathrm{OS}[\mathrm{M}+\mathrm{H}]^{+}:$229.1626; found: 229.1655 .

\section{3-(Dodecylthio)-3,7-dimethyloct-6-enal (3c)}

${ }^{1} \mathrm{H}$ NMR $\left(400 \mathrm{MHz}, \mathrm{CDCl}_{3}\right) \delta(\mathrm{ppm}) 0.88(\mathrm{t}, J$ 7.0, $3 \mathrm{H}) ; 1.40$ (s, 3H); 1.10-1.80 (m, 22H); 1.62 (s, 3H); 1.68 (s, 3H); 2.05-2.15 (m, 2H); 2.44-2.54 (m, 4H); 5.05-5.12 $(\mathrm{m}, 1 \mathrm{H}) ; 9.90(\mathrm{dd}, J 3.0$ and $2.0,1 \mathrm{H}) ;{ }^{13} \mathrm{C}$ NMR $(100 \mathrm{MHz}$, $\left.\mathrm{CDCl}_{3}\right) \delta(\mathrm{ppm}) 14.1,17.6,22.7,22.8,25.6,26.3,27.5$, 
29.2, 29.23, 29.28, 29.32, 29.48, 29.57, 29.6, 31.9, 41.0, 45.7, 52.7, 123.5, 132.2, 201.6. MS m/z (rel. int., \%) 354 $\left(\mathrm{M}^{+}, 0.6\right), 134$ (73.6), 69 (100.0). HRMS (ESI): $\mathrm{m} / \mathrm{z}$ calc. for $\mathrm{C}_{22} \mathrm{H}_{42} \mathrm{OS}[\mathrm{M}+\mathrm{H}]^{+}$: 355.3035; found: 355.3041 .

\section{3-(2-Chlorophenylthio)-3,7-dimethyloct-6-enal (3d)}

${ }^{1} \mathrm{H}$ NMR (400 MHz, $\mathrm{CDCl}_{3}$ ) $\delta(\mathrm{ppm}) 1.37$ (s, 3H); 1.63 (s, 3H); 1.69 (s, 3H); 1.60-1.75 (m, 2H); 2.16-2.26 (m, 2H); 2.53-2.57 (m, 2H); 5.04-5.12 (m, 1H); 7.24 (dt, $J 7.6$ and $1.6,1 \mathrm{H}) ; 7.32$ (dt, $J 7.2$ and $1.6,1 \mathrm{H}) ; 7.60(\mathrm{dd}, J 7.2$ and $2.0,1 \mathrm{H}) ; 7.48(\mathrm{dd}, J 7.2$ and $2.0,1 \mathrm{H}) ; 9.90(\mathrm{dd}, J 2.8$ and $2.4,1 \mathrm{H}) ;{ }^{13} \mathrm{C}$ NMR $\left(50 \mathrm{MHz}, \mathrm{CDCl}_{3}\right) \delta$ (ppm) 17.7, 23.1, 25.6, 26.3, 51.9, 52.4, 123.2, 126.9, 130.4, 132.3, 133.6, 141.2, 201.8. HRMS (ESI): $\mathrm{m} / z$ calc. for $\mathrm{C}_{16} \mathrm{H}_{21} \mathrm{ClOS}$ [M $+\mathrm{Na}]^{+}:$319.0894; found: 319.0885 .

\section{3-(4-Methoxyphenylthio)-3,7-dimethyloct-6-enal (3e)}

${ }^{1} \mathrm{H}$ NMR $\left(400 \mathrm{MHz}, \mathrm{CDCl}_{3}\right) \delta(\mathrm{ppm}) 1.32$ (s, 3H); 1.541.60 (m, 2H); 1.62 (s, 3H); 1.67 (s, 3H); 2.10-2.20 (m, 3H); $2.40(\mathrm{~d}, J$ 2.0, 1H); $3.77(\mathrm{~s}, 3 \mathrm{H}) ; 5.03-5.01(\mathrm{~m}, 1 \mathrm{H}) ; 6.84$ $(\mathrm{d}, J 8.8,2 \mathrm{H}) ; 7.38$ (d, $J$ 8.8, 2H); 9.90 (dd, $J 2.4$ and 2.8, $1 \mathrm{H}) ;{ }^{13} \mathrm{C} \mathrm{NMR}\left(100 \mathrm{MHz}, \mathrm{CDCl}_{3}\right) \delta(\mathrm{ppm}) 17.2,22.5,25.2$, 25.5, 48.9, 51.7, 54.7, 123.1, 126.8, 128.1, 131.4, 132.1, 138.5, 201.1. HRMS (ESI): $\mathrm{m} / z$ calc. for $\mathrm{C}_{17} \mathrm{H}_{24} \mathrm{O}_{2} \mathrm{~S}[\mathrm{M}+$ $\mathrm{H}]^{+}:$293.1575; found: 293.1575 .

\section{3-(Phenylthio)cyclohexanone (4) ${ }^{32}$}

${ }^{1} \mathrm{H}$ NMR $\left(200 \mathrm{MHz}, \mathrm{CDCl}_{3}\right) \delta(\mathrm{ppm})$ 1.68-1.82 (m, $2 \mathrm{H}) ; 2.07-2.28(\mathrm{~m}, 2 \mathrm{H}) ; 2.27-2.42(\mathrm{~m}, 3 \mathrm{H}) ; 2.63-2.72(\mathrm{~m}$, $1 \mathrm{H})$; 3.35-3.49 (m, $1 \mathrm{H})$; 7.28-7.38 (m, 3H); 7.44-7.50 (m, $2 \mathrm{H}) ;{ }^{13} \mathrm{C} \mathrm{NMR}\left(100 \mathrm{MHz}, \mathrm{CDCl}_{3}\right) \delta(\mathrm{ppm}) 23.8,31.0,40.6$, 45.9, 47.5, 127.5, 128.9, 132.8, 132.9, 208.4. MS m/z (rel. int., \%) $206\left(\mathrm{M}^{+}, 55.9\right), 109$ (15.5), 69 (100.0).

\section{3-(4-Chlorophenylthio)cyclohexanone $(\mathbf{6})^{20}$}

${ }^{1} \mathrm{H}$ NMR (200 MHz, $\mathrm{CDCl}_{3}$ ) $\delta(\mathrm{ppm})$ 1,70-1,81 (m, $2 \mathrm{H}) ; 2.07-2.41(\mathrm{~m}, 5 \mathrm{H}) ; 2.59-2.68(\mathrm{~m}, 1 \mathrm{H}) ; 3.30-3.47(\mathrm{~m}$, $1 \mathrm{H}) ; 7.28-7.41$ (m, 4H).

\section{3-(Phenylthio)propanenitrile (7) $)^{19,33,34}$}

${ }^{1} \mathrm{H} \mathrm{NMR}\left(200 \mathrm{MHz}, \mathrm{CDCl}_{3}\right) \delta(\mathrm{ppm}) 2.57$ (t, J 7.2, 2H); $3.11(\mathrm{t}, J 7.4,2 \mathrm{H}) ; 7.28-7.40(\mathrm{~m}, 5 \mathrm{H}) ;{ }^{13} \mathrm{C}$ NMR $(100 \mathrm{MHz}$, $\left.\mathrm{CDCl}_{3}\right) \delta(\mathrm{ppm}) 17.9,29.8,117.8,127.3,129.1,130.9$, 133.0. MS m/z (rel. int., \%) $163\left(\mathrm{M}^{+}, 57.3\right), 123$ (100.0), 109 (12.8), 77 (12.9).

\section{3-(4-Chlorophenylthio)propanenitrile $(\boldsymbol{8})^{33,34}$}

${ }^{1} \mathrm{H}$ NMR $\left(200 \mathrm{MHz}, \mathrm{CDCl}_{3}\right) \delta(\mathrm{ppm}) 2.59(\mathrm{t}, J$ 7.2, $2 \mathrm{H}) ; 3.10(\mathrm{t}, J 7.2,2 \mathrm{H}) ; 7.25-7.37$ (m, 4H); ${ }^{13} \mathrm{C}$ NMR (50 $\left.\mathrm{MHz}, \mathrm{CDCl}_{3}\right) \delta$ (ppm) 18.1, 30.2, 117.7, 129.4, 131.6, $132.5,133.7$.

\section{3-(Propylthio)propanenitrile $(\mathbf{9})^{34}$}

${ }^{1} \mathrm{H}$ NMR (200 MHz, $\left.\mathrm{CDCl}_{3}\right) \delta(\mathrm{ppm}) 1.00$ (t, J 7.2, $3 \mathrm{H}$ ); 1.63 (sext, $J$ 7.2, 2H); 2.54-2.67 (m, 4H); 2.75-2.83 $(\mathrm{m}, 2 \mathrm{H})$.

\section{Methyl 3-(phenylthio)propanoate (10) $)^{34,35}$}

${ }^{1} \mathrm{H} \mathrm{NMR}\left(200 \mathrm{MHz}, \mathrm{CDCl}_{3}\right) \delta(\mathrm{ppm}) 2.60(\mathrm{t}, J 7.2,2 \mathrm{H})$; $3.14(\mathrm{t}, J 7.2,2 \mathrm{H}) ; 3.63(\mathrm{~s}, 3 \mathrm{H}) ; 7.17-7.40(\mathrm{~m}, 5 \mathrm{H}) ;{ }^{13} \mathrm{C}$ NMR (50 MHz, $\left.\mathrm{CDCl}_{3}\right) \delta$ (ppm) 28.8, 34.0, 51.6, 126.4, 128.9, 129.9, 135.1, 171.9.

\section{Methyl 3-(4-Chlorophenylthio)propanoate $(11)^{34,35}$}

${ }^{1} \mathrm{H} \mathrm{NMR}\left(200 \mathrm{MHz}, \mathrm{CDCl}_{3}\right) \delta(\mathrm{ppm}) 2.63(\mathrm{t}, J 7.0,2 \mathrm{H})$; $3.17(\mathrm{t}, J 7.0,2 \mathrm{H}) ; 3.60$ (s, 3H); 7.21-7.40 (m, 4H). MS m/z (rel. int., \%) 230 (M+, 100.0), 170 (56.2), 157 (62.6), 108 (49.7), 59 (50.5).

\section{3-(Phenylthio)propanoic acid $(\mathbf{1 2})^{36}$}

${ }^{1} \mathrm{H}$ NMR $\left(200 \mathrm{MHz}, \mathrm{CDCl}_{3}\right) \delta(\mathrm{ppm}) 2.67$ (t, J 7.6, 2H); $3.16(\mathrm{t}, J 7.2,2 \mathrm{H}) ; 7.17-7.40(\mathrm{~m}, 5 \mathrm{H}) ;{ }^{13} \mathrm{C}$ NMR $(100 \mathrm{MHz}$, $\left.\mathrm{CDCl}_{3}\right) \delta(\mathrm{ppm}) 28.8,34.1,126.8,129.1,130.3,134.9$, 177.3. MS m/z (rel. int., \%) $182\left(\mathrm{M}^{+}, 92.0\right), 123$ (100.0), 109 (33.7), 77 (17.2).

\section{Results and Discussion}

Our initial efforts were made towards the determination of the optimum conditions to perform the solvent-free protocol. Thus, we choose citral (1a), easily available from essential oil of lemon grass (Cymbopogon citratus) and thiophenol (2a) to establish the best conditions for the Michael addition.

With the aim to promote the selective 1,4-nucleophilic addition, several reaction conditions were tested, and the best results were obtained when citral (1a, $1 \mathrm{mmol})$ was added to a mixture of thiophenol (2a, $1.2 \mathrm{mmol})$ and $\mathrm{KF} / \mathrm{Al}_{2} \mathrm{O}_{3}(50 \%, 0.07 \mathrm{~g})$ at room temperature and stirred for $4 \mathrm{~h}$ (Scheme 1, entry 1, Table 1).

The use of a larger amount of $\mathrm{KF} / \mathrm{Al}_{2} \mathrm{O}_{3}(50 \%)$, or of a larger concentration of $\mathrm{KF}(60 \% \mathrm{~m} / \mathrm{m})$ did not increase the yield of 3a. On the other hand, using $0.050 \mathrm{~g}$ of $\mathrm{KF} / \mathrm{Al}_{2} \mathrm{O}_{3}$ $(50 \%)$ at room temperature makes the reaction proceed slowly, in $40 \%$ yield after 12 hours. Aiming to reduce the reaction time, the mixture was irradiated with microwaves. The product 3a was obtained in good yield after 6 min of irradiation at $548 \mathrm{~W}$ (entry 2, Table 1). It was observed that the protocol works with aromatic and aliphatic thiols, and it can be extended to a variety of electron-poor alkenes (ester, acid, nitrile and ketone). The experimental procedure is very easy, and the products were obtained after stirring a few hours at room temperature or irradiated for few minutes with 
microwaves (Table 1). The best conditions were extended to others thiols $\mathbf{2}$ and a series of thio-functionalyzed aldehydes were obtained in moderated to good yields (entries 3-10, Table 1). It was observed that the catalytic system can be re-used for 3 cycles, just by washing it with ethyl acetate and drying under vacuum. The recycled catalytic system was successfully employed to both the methods, at room temperature and under microwave irradiation.

Despite the good yields and generality of the solvent-free protocol described above, the method is restricted to room temperature liquid thiols. To circumvent this limitation, but maintaining our focal point, i.e., a cleaner procedure for the Michael addition, we decide to expand the scope of our protocol to others liquids and solids thiols and electron deficient alkenes. Thus the use of recyclable glycerin, a renewable feedstock easily available as a co-product in biodiesel production, was studied as a solvent in this reaction (Method C, Table 1). The best yields were obtained when the alkene $(1,1 \mathrm{mmol})$ was added to a mixture of the glycerin $(1 \mathrm{~mL}), \mathrm{KF} / \mathrm{Al}_{2} \mathrm{O}_{3}$ $(50 \%, 0.07 \mathrm{~g})$ and the thiol $(2,1.2 \mathrm{mmol})$ and vigorously stirred at room temperature for 2-4 hours (Method C, Table 1). By using glycerin as solvent, it was possible to add the solid p-chlorothiophenol (2g) to cyclohex-2-enone (1b), affording the respective Michael adduct $\mathbf{6}$ in $70 \%$ yield after stirring at room temperature for 2.5 hours (entry 14, Table 1). Besides cyclohex-2-enone, glycerin was a good solvent also for the reaction of others alkenes, such as citral, acrylonitrile and methyl acrylate. When acrylic acid (1e) was used, however, 3-(Phenylthio)propanoic acid (12) was obtained only in $15 \%$ yield, even after several hours of stirring or under heating at $60{ }^{\circ} \mathrm{C}$ (entry 21, Table 1). For the acrylic acid, the best method is the solvent-free one, which gives the product 12 in $80 \%$ yield after stirring for 3 hours at room temperature (entry 20). The mixture of glycerin and $\mathrm{KF} / \mathrm{Al}_{2} \mathrm{O}_{3}$ was re-used up to 3 times without loss of the activity by simple addition of more thiol and alkene to the remaining crude in the reaction vessel after washing with ether.

When we carried out the reaction using glycerin in the absence of supported catalyst, to verify the role of the $\mathrm{KF} / \mathrm{Al}_{2} \mathrm{O}_{3}$, we observed slow consumption of starting materials and competition between 1,4- and 1,2-additions. Thus, when citral (1a, $1 \mathrm{mmol}$ ) reacted with thiophenol (2a, $1.2 \mathrm{mmol})$ in the presence of glycerin $(1 \mathrm{~mL})$, a mixture of Michael adduct 3a and the respective dithioacetal 13, along with unreacted citral, was formed after 3 hours of stirring at room temperature (Scheme 2). Glycerin is a good solvent also to perform the reaction between citral and thiophenol (2 equiv.) using acid catalysis $\left(\mathrm{H}_{2} \mathrm{SO}_{4}, 0.5 \mathrm{~mol} \%\right.$ ), affording selectively the respective dithioacetal 13 in $86 \%$ yield after 2 hours at room temperature (Scheme 2).

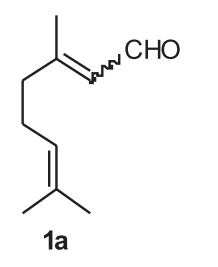

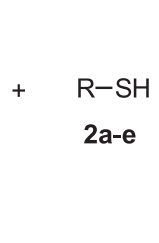

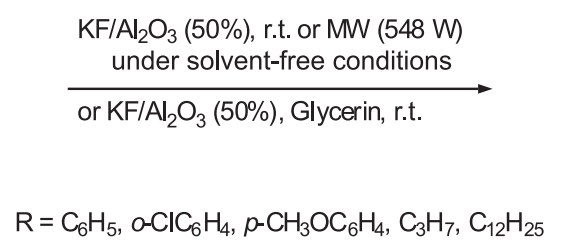

Scheme 1.

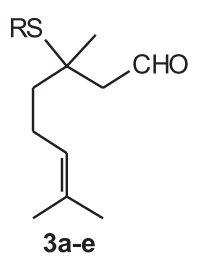

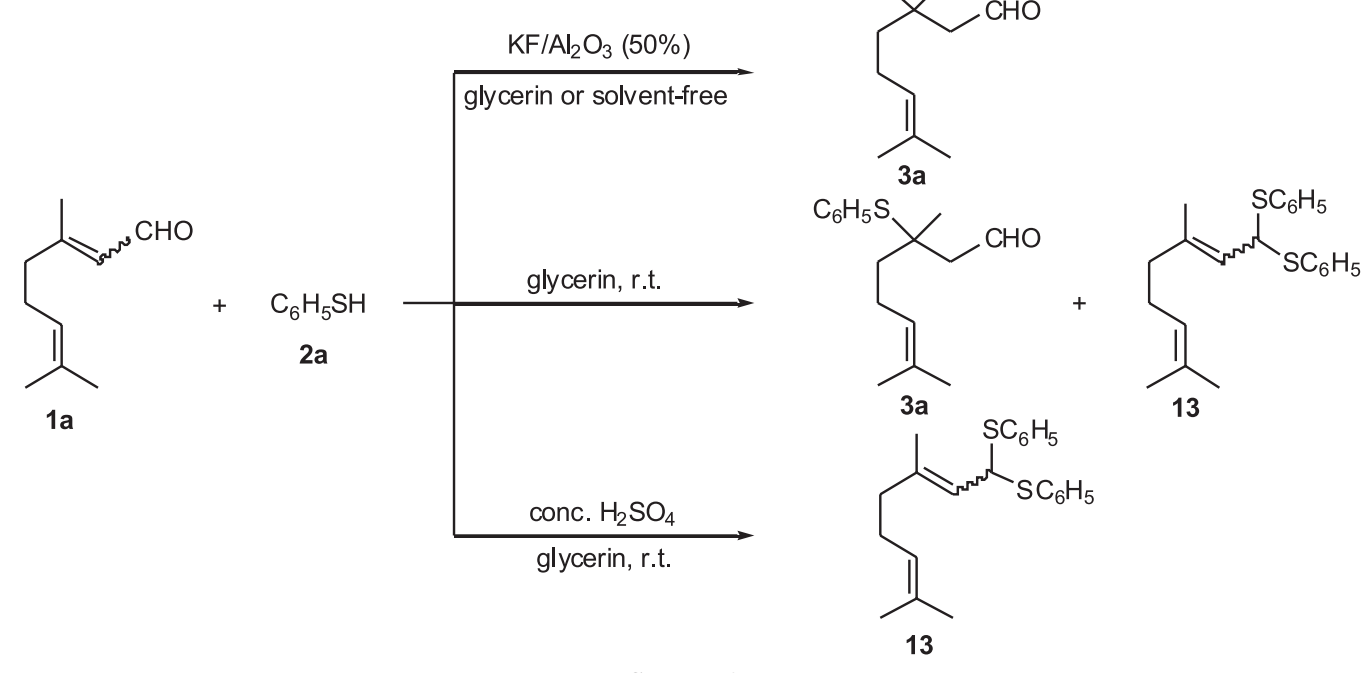

Scheme 2. 
Table 1. Conjugated addition of thiols to citral and electron-poor alkenes under solvent-free conditions or using glycerin

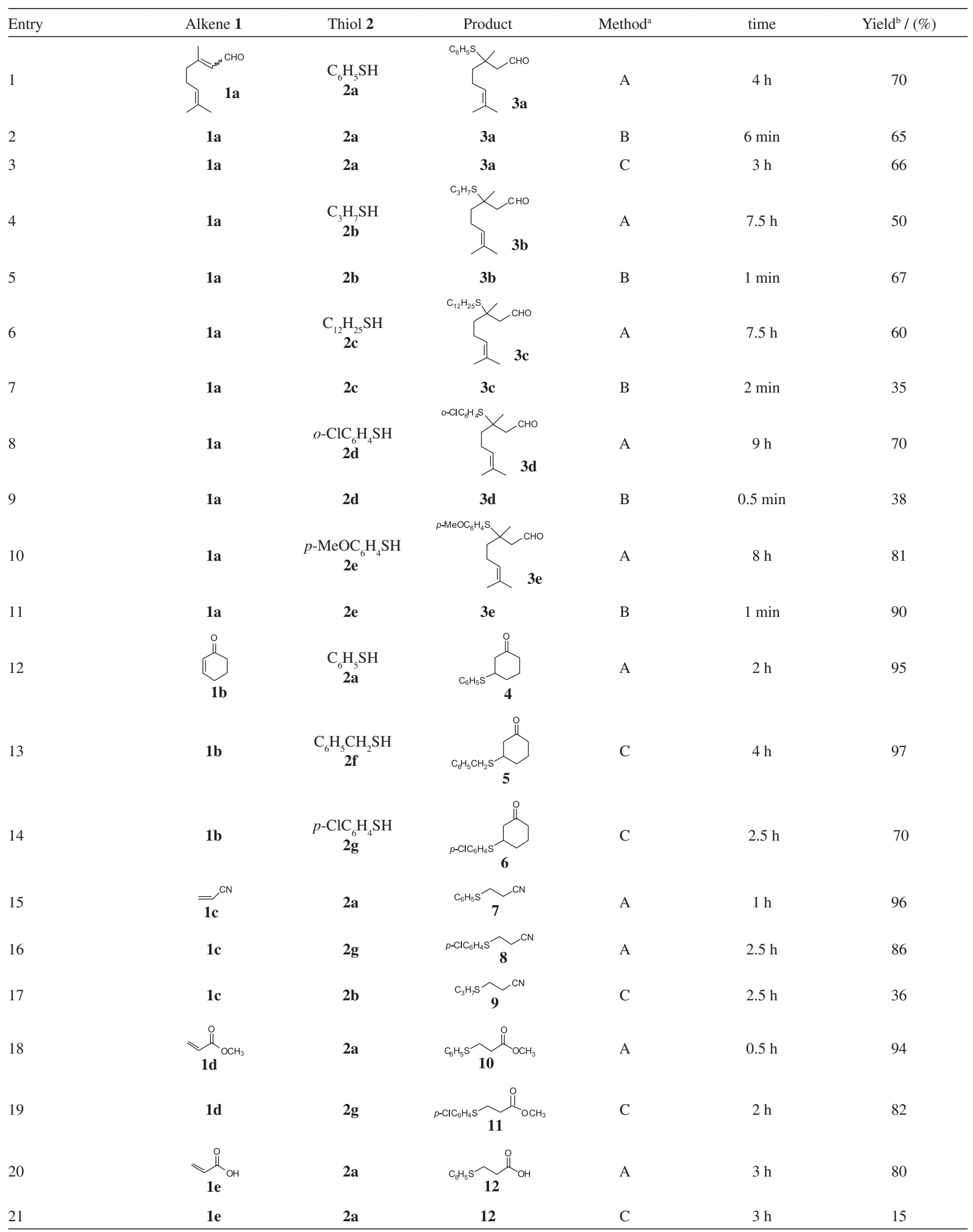

${ }^{a}$ Method A: The experiments were performed at room temperature. Method B: The experiments were performed under MW at 548 W. Method C: The experiments were performed at room temperature using glycerin $\left(1 \mathrm{~mL}\right.$ per mmol) as solvent; ${ }^{b}$ Yields in pure products isolated by chromatography (AcOEt/ hexanes) and identified by mass spectra, ${ }^{1} \mathrm{H}$ and ${ }^{13} \mathrm{C}$ NMR. 
Due to our interest in the synthetic use of the essential oils of plants cultivated in Southern Brazil and their constituents as renewable raw materials for use in organic synthesis, we tried to use one of our reaction conditions $\left(\mathrm{KF} / \mathrm{Al}_{2} \mathrm{O}_{3}(50 \%)\right.$ under MW) in the direct 1,4-addition of thiophenol to the crude lemon grass oil (Cymbopogon citratus). The major component of the essential oil of lemon grass, extracted from the plant grown in Southern Brazil was found to be citral (80-85\%). ${ }^{29}$ Thus, when a mixture of thiophenol (2a) and the essential oil of lemon grass was submitted to MW irradiation (548W) for $0.5 \mathrm{~min}$ in the presence of $\mathrm{KF} / \mathrm{Al}_{2} \mathrm{O}_{3}$ (50\%, $0.07 \mathrm{~g}$ ), 3,7-dimethyl-3-(phenylthio)oct-6-enal (3a) was obtained in $52 \%$ yield, together with unreacted mircene, linalool, geraniol and others minor constituents of the starting oil, that were recovered.

The thio-functionalyzed aldehydes 3a-e were tested for their antimicrobial activity and preliminary studies showed that all of them present bactericide activity against Staphylococcus sp. The antimicrobial activity of some thio-functionalyzed aldehydes was higher than that observed for the parent citral or even for non-functionalized citronellal. ${ }^{15}$

In conclusion, we have presented here an easy and general method for the preparation of new 3-thioorganylcitronellal derivatives with antimicrobial activity. This eco-friendly protocol can be successfully applied to the synthesis of 3,7-dimethyl-3-(phenylthio) oct-6-enal (3a) from crude lemon grass oil, avoiding the necessity for the separation of citral (1a). Glycerin was successfully used as a renewable, non-toxic and recyclable solvent, opening new possibilities for future applications of glycerin in green and sustainable chemistry. The procedures are very simple, makes use of renewable and easily available starting materials, no-solvent or a recyclable one, and the catalytic system can be re-used. The use of microwaves accelerates the solvent-free reaction with comparable yields in most of examples.

\section{Acknowledgments}

This project was funded by FAPERGS, CNPq and CAPES. Prof. Lopes, N. P. (HRMS), from FCFRP-USP and Pinto, J. P. (LRMS), from UEL, are thanked for the analyses. We are in debt to Pólo Oleoquímico de Três Passos/UNIJUÍ (Brazil) for providing the essential oil of lemon grass.

\section{References}

1. Lenardão, E. J.; Botteselle, G. V.; Azambuja, F.; Perin, G.; Jacob, R. G.; Tetrahedron 2007, 63, 6671.
2. Fluharty, A. L. In The Chemistry of Thiol Group; Patai, S., ed.; Wiley: New York, 1974, Part 2, p. 589.

3. Hall, I. H.; Lee, K.-H.; Mar, E. C.; Starnes, C. O.; Waddell, T. G.; J. Med. Chem. 1977, 20, 333.

4. Paterson, I.; Laffan, D. D. P.; Rawson, D. J.; Tetrahedron Lett. 1988, 29, 1461.

5. Anastas, P. T.; Warner, J.; Green Chemistry: Theory and Practice, Oxford University Press: Oxford, 1998.

6. Lenardão, E. J.; Freitag, R. A.; Dabdoub, M. J.; Batista, A. C.; Silveira, C. C.; Quim. Nova 2003, 26, 123.

7. Trost, B. M.; Science 1991, 254, 1471.

8. Li, M.; Huang, J.; Zahng, W.; React. Funct. Polym. 2001, 47, 71.

9. Abrouki, Y.; Zahouly, M.; Rayadh, A.; Bahlaouan, B.; Sebti, S.; Tetrahedron Lett. 2002, 43, 8951.

10. Zahouily, M.; Abrouki, Y.; Rayadh, A.; Tetrahedron Lett. 2002, 43, 7729 .

11. Sharma, G.; Kumar, R.; Chakraborti, A. K.; J. Mol. Catal. A: Chem. 2007, 263, 143.

12. Keiko, N. A.; Funtikova, E. A.; Stepanova, L. G.; Chuvashev, Y. A.; Larina, L. I.; ARKIVOC 2001, 67.

13. Moghaddam, F. M.; Bardajee, G. R.; Veranlou, R. O. C.; Synth. Commun. 2005, 35, 2427.

14. Bartoli, G.; Bartolacci, M.; Giuliani, A.; Marcantoni, E.; Massaccesi, M.; Torregiani, E.; J. Org. Chem. 2005, 70, 169.

15. Lenardão, E. J.; Ferreira, P. C.; Jacob, R. G.; Perin, G.; Leite, F. P. L.; Tetrahedron Lett. 2007, 48, 6763.

16. Yang, L.; Xu, L. W.; Xia, C. G.; Tetrahedron Lett. 2005, 46, 3279.

17. Manickam, G.; Sundararajan, G.; Tetrahedron 1999, 55, 2721.

18. Yadav, J. S.; Reddy, B. V. S.; Baishya, G.; J. Org. Chem. 2003, 68, 7098.

19. Ranu, B. C.; Dey, S. S.; Hajra, A.; Tetrahedron 2003, 59, 2417.

20. Hiemstra, H.; Wynberg, H.; J. Am. Chem. Soc. 1981, 103, 417.

21. For a review on enantioselective conjugated additions, see: Sibi, M. P.; Manyem, S.; Tetrahedron 2000, 56, 8033.

22. Silva, F. M.; Jones Jr., J.; J. Braz. Chem. Soc. 2001, 12, 135.

23. Almeida, Q. A. R.; Pereira, M. L. O.; Coelho, R. B.; Carvalho, E. M.; Kaiser, C. R.; Jones Jr., J.; Silva, F. M.; J. Braz. Chem. Soc. 2008, 19, 894.

24. Bakuzis, P.; Bakuzis, M. L. F.; J. Org. Chem. 1981, 46, 235.

25. Jacob, R. G.; Perin, G.; Loi, L. N.; Pinno, C. S.; Lenardão, E. J.; Tetrahedron Lett. 2003, 44, 3605.

26. Jacob, R. G.; Perin, G.; Botteselle, G. V.; Lenardão, E. J.; Tetrahedron Lett. 2003, 44, 6809.

27. Lenardão, E. J.; Mendes, S. R.; Ferreira, P. C.; Perin, G.; Silveira, C. C.; Jacob, R. G.; Tetrahedron Lett. 2006, 47, 7439. 
28. Perin, G.; Álvaro, G.; Westphal, E.; Viana, L. H.; Jacob, R. G.; Lenardão, E. J.; D’Oca, M. G. M.; Fuel 2008, 87, 2838.

29. Paviani, L.; Pergher, S. B. C.; Dariva, C.; Braz. J. Chem. Eng. 2006, 23, 219.

30. Wang, S.-X.; Li, J.-T.; Yang, W.-Z.; Li, T.-S.; Ultrason. Sonochem. 2002, 9, 159.

31. The oven powers were determined as described by Kingston, H. M.; Introduction to Microwave Sample Preparation-Theory and Practice; Jassie, L. B., ed.; American Chemical Society: DC, 1988.
32. Chu, C-M.; Gao, S.; Sastry, M. N. V.; Kuo, C-W.; Lu, C.; Liu, J.-T.; Yao, C-F.; Tetrahedron 2007, 63, 1863.

33. Ricci, A.; Danieli, R.; Pirazzini, G.; J. Chem. Soc., Perkin Trans. I 1977, 1069.

34. Kamal, A.; Rajendar, D. R. R.; Tetrahedron Lett. 2005, 46, 7951.

35. Iqbal, J.; Sukla, A.; Tetrahedron 1991, 47, 8753.

36. Gao, S.; Tseng, C.; Tsai, C. H.; Yao, C.-F.; Tetrahedron 2008 , 64, 1955. 